\title{
MAKNA TUJUH UNGKAPAN YESUS DI SALIB BAGI ORANG PERCAYA
}

\author{
Aldorio Flavius Lele ${ }^{1)^{*}}$, Robi Panggarra ${ }^{2)}$ \\ 1) Alumni Sekolah Tinggi Theologia Jaffray \\ ${ }^{2)}$ Dosen Prodi Teologi Sekolah Tinggi Theologia Jaffray \\ ${ }^{*}$ Penulis korespondensi: aldorioflavius@gmail.com
}

\begin{abstract}
Abstrak
Tujuh perkataan Yesus di kayu salib merupakan tujuh ucapan yang mencakup seluruh pengajaran mengenai kasih Allah bagi manusia. Kasih yang sulit untuk dipahami, sulit untuk dimengerti secara tuntas karena ia melebihi kapasitas serta rasio pemikiran manusia yang terbatas. Pernyataan kasih itu disimpulkan sebagai berikut: Pertama, ucapan pengampunan yang diucapkan Yesus mengajarkan bahwa prinsip pengampunan adalah mengasihi musuh. Mendoakan dan mengharapkan dia bertobat serta mengampuni segala dosadosanya bukan berarti membiarkan dia berdosa terus menerus. Ucapan pengampunan yang diucapkan oleh Yesus ialah bukan supaya orang-orang yang didoakan diampuni tanpa pertobatan, tetapi supaya mereka diampuni melalui pertobatan. Kedua, dalam perkataan-Nya yang kedua, Yesus menjamin orang berdosa yang bertobat dan percaya kepada-Nya akan bersama-sama dengan Dia di Firdaus. Seruan jaminan kepastian yang diucapkan Yesus merupakan bentuk kasih yang menyelamatkan. Ketiga, Yesus adalah Allah yang peduli terhadap penderitaan umat yang dikasihi-Nya. Orang-orang yang sungguh-sungguh mengasihi Tuhan memiliki tanggung jawab untuk melakukan segala perintah Tuhan dan dalam segala hal mengasihi sesama. Keempat, Seruan ini mengajarkan mengenai kuasa dosa yang dahsyat sehingga Allah Bapa merelakan Anak-Nya yang sangat Ia kasihi, memikul beban dosa tanpa pertolongan dan perlindungan. Kelima, ucapan kelima inilah satu-satunya ucapan yang berhubungan dengan kesakitan jasmani yang Ia ucapkan dari atas kayu salib. Rasa haus Yesus menunjukkan bahwa Ia adalah benar-benar manusia. Ia adalah sumber air hidup yang rela menderita agar dapat menyelamatkan mereka yang datang kepada-Nya. Keenam, ucapan keenam ini bukanlah teriakan kekalahan, melainkan teriakan kemenangan. Ketaatan-Nya kepada kehendak Bapa hingga akhir hidup-Nya menandakan kasih-Nya yang begitu besar bagi manusia. Inilah kasih yang taat sampai mati. Ketujuh, ucapan terakhir Yesus menjelang kematian-Nya adalah sebuah doa. Di dalam doa-Nya itu Ia mengajarkan orang percaya bagaimana menghadapi kematian. Bentuk kasih yang penuh, terkandung di dalam penyerahan total kepada Allah.
\end{abstract}

Kata-kata kunci: pengampunan, kasih, Kristus, keselamatan, Yesus, kamatian, salib 
The seven statements of Jesus on the cross are seven declarations which encompass all the teachings about God's love for people. This love is difficult to comprehend, difficult to completely understand because it is beyond the limited capacity, including the reasoning ability of man. These statements can be summarized as follows: First, the pronunciation of forgiveness which Jesus uttered teaches that a principle of forgiveness is loving one's enemies. Praying and hoping that they repent, as well as forgiving all of their sins, does not mean allowing them to continue to sin. Jesus' statement about forgiveness was not so that people which are prayed for are forgiven without repentance, but that they are forgiven through repentance. Second, Jesus guarantees that the sinner that repents and believes in him will be together with him in Paradise. Jesus' statement of certain assurance shows the nature of saving love. Third, Jesus is the God who cares about the sufferings of his people whom he loves. People which genuinely love the Lord have a responsibility to obey all of the Lord's commands and in everything love their fellow man. Fourth, the fourth appeal teaches about the power of sin which is so devastating that God the Father offered his beloved Son to shoulder the burden of sin without help or support. Fifth, this fifth cry is the only utterance which he makes from the cross which makes reference to his physical pain. Jesus' thirst shows that he really is man. He is the source of living water who is willing to suffer in order to save those who come to him. Sixth, the sixth declaration is not a cry of defeat, but rather a cry of victory. His obedience to the will of his Father until the end of his life shows the greatness of his love toward people. This is love that is obedient until death. Seventh, the final statement of Jesus before his death is a prayer. In his prayer, he teaches believers how to face death. The nature of a love that is comprehensive is contained in complete surrender to God.

Keywords: forgiveness, love, Christ, salvation, Jesus, death, cross

\section{Pendahuluan}

Salib merupakan peristiwa yang paling bersejarah dalam dunia kekristenan. Peristiwa salib yang ditulis oleh kitab-kitab Injil terjadi tepatnya di sebuah tempat yang bernama bukit Golgota. Di Golgota inilah pernah terjadi penyiksaan besar-besaran yang dilakukan oleh orang banyak kepada seorang yang tidak bersalah. Golgota, saat yang paling gelap dalam sejarah dunia di mana kejahatan dan keganasan akibat dosa merajalela. Seperti yang dikatakan oleh Andar Lumbantobing dalam bukunya:

Golgota! Gelap gulita melayang-layang di atasnya! Di Golgotalah memuncak segala kecemaran, keburukan dan dosa manusia. Di sanalah manusia melampiaskan rasa dendamnya terhadap Yesus, terhadap Tuhan 
Allah. Golgota! Saat yang hitam-lebam dalam sejarah dunia. Golgota! Saat merajalela keganasan kegelapan. ${ }^{1}$

Di atas salib Golgota diperlihatkan hal yang paling besar di dunia, yaitu kasih; rahasia yang paling gelap dari alam semesta, yaitu dosa; dan ungkapan yang paling luhur dari kodrat dan watak Allah, yaitu kekudusan. $^{2}$

Salib pada masa itu adalah bentuk hukuman orang romawi yang mengandung pesan takut dan malu yang begitu kuat. Mereka yang di salib dianggap hina, sehingga melalui peristiwa salib, setiap orang di desak untuk berpikir ulang jika berlawanan dengan penguasa karena juga akan mewariskan rasa malu bagi keluarga yang ditinggalkan. Hal ini menjelaskan mengapa salib telah menjadi alat untuk menebar terror kepada banyak orang. Namun, semua keadaan salib berhasil dijungkirbalikkan oleh Yesus yang dalam penderitaan-Nya mampu memperlihatkan konsistensi-Nya. Rasa takut dan malu akibat dosa telah diganti dengan kekuatan untuk menatap setiap masalah dengan kepala tegak oleh karena kasih karunia-Nya. Pada titik inilah peristiwa salib mengalami perubahan makna pesan, sebab kini pesannya adalah "jangan takut" dan "jangan malu". Pesan ini bergema di semua lini kehidupan orang percaya. Pesan Yesus itu terbaca juga dari setiap kata yang diucapkan-Nya ketika berada di salib. Itulah kata-kata yang mengubah penampilan dan makna salib menjadi simbol dari pesan Allah kepada dunia "Aku mengasihimu" (bdn. Yoh.3:16). Maka, kehidupan orang kristen yang membawa salib dalam kehidupannya bukanlah tanpa arti. Orang Kristen yang memikul salib kini mendapat makna baru sebagai manusia yang menerima pesan kuat dari Tuhan bahwa Ia sudah mengubah makna salib. Makna perubahan itu nampak dari kata-kata Yesus di salib. ${ }^{3}$

Jika salib Kristus mempunyai suatu arti yang begitu penting, maka salib Kristus merupakan kenyataan yang paling dalam dan rahasia yang paling luhur. Orang akan menyadari bahwa dalam arti yang sebenarnya segala kekayaan dan kemuliaan Injil berpusat di sini. ${ }^{4}$ Tidak ada peristiwa lain sepanjang masa yang lebih penting dari pada kematian Kristus di kayu salib. Perbuatan-perbuatan penting lainnya dari Allah seperti di dalam penciptaan dunia, inkarnasi Kristus, kebangkitan-Nya,

${ }^{1}$ Andar Lumbantobing, Tudjuh Utjapan Tuhan Jesus di Kayu Salib (Jakarta: BPK, 1989),

5.

${ }^{2}$ Samuel Zwemer, Kemuliaan Salib (Jakarta: Badan Penerbit Kristen, 2002), 60.

3 Alex Letlora, 7 Perkataan Yesus di Salib, diakses 6 Februari 2014, http://alexletlora.com/index.php?ipage=143

${ }^{4}$ Ibid., 60. 
kedatangan kedua kali-Nya, dan penciptaan langit dan bumi baru menjadi tidak ada artinya apabila Kristus tidak mati. ${ }^{3}$

Yesus Kristus menyatakan pesan terakhir-Nya menjelang kematianNya di atas kayu salib. Yesus tidak meninggalkan tulisan apapun. Dia mengajar murid-murid-Nya sebagaimana seorang guru mengajar muridnya. Mereka diharapkan untuk mengingat ungkapan dan perbuatan sang guru. ${ }^{6}$ Ketujuh kalimat yang berupa pesan akhir yang begitu agung dan mulia serta memiliki pengaruh yang sungguh luar biasa yang tercatat di dalam seluruh sejarah dunia, seperti yang juga dikemukakan oleh Stephen Tong dalam bukunya:

Namun sejarah mencatat satu-satunya kasus yang terkecuali, yaitu pada waktu Kristus di salib. Tidak lebih, tidak kurang Ia mengucapkan tujuh kalimat. Ketujuh kalimat ini menenun satu gambaran kosmos yang menyatakan keagungan jiwa Sang Penebus, mengungkapkan kebesaran rencana penebusan Allah bagi manusia, mengejutkan sang raja kerajaan gelap, dan yang menghibur umat manusia di tengah kegelapan, dan yang menerangi jiwa-jiwa yang tersesat untuk selamanya. ${ }^{7}$

Yesus yang menjadi daging dan datang ke dunia ini dalam pemeliharaan Allah, mengatakan tujuh ungkapan di kayu salib saat Ia menghembuskan napas terakhir-Nya. ${ }^{8}$ Ungkapan itu antara lain adalah sebagai berikut: ${ }^{9}$

Ungkapan Pertama: "Ya Bapa, ampunilah mereka, sebab mereka tidak tahu apa yang mereka perbuat" (Lukas 23:34).

Ungkapan Kedua: "Aku berkata kepadamu, sesungguhnya hari ini juga engkau akan ada bersama-sama dengan Aku di dalam Firdaus" (Lukas 23:43).

Ungkapan Ketiga: "Ibu, inilah, anakmu!" ... "Inilah ibumu!" (Yohanes 19:26-27).

Ungkapan Keempat: "Allah-Ku, Allah-Ku, mengapa Engkau meninggalkan Aku?” (Matius 27:46; Markus 15:34).

Ungkapan Kelima: "Aku haus!" (Yohanes 19:28).

Ungkapan Keenam : "Sudah selesai" (Yohanes 19:30).

Ungkapan Ketujuh : "Ya Bapa, ke dalam tangan-Mu Kuserahkan nyawa-Ku" (Lukas 23:46).

\footnotetext{
${ }^{5}$ John F. Walvoord, Yesus Kristus Tuhan Kita (Surabaya: YAKIN, 1969), 142.

${ }^{6}$ Peter H. Davids, Ucapan Yang Sulit Dalam Perjanjian Baru (Malang: Literatur SAAT, 2000), 91.

${ }^{7}$ Stephen Tong, 7 Perkataan Salib (Jakarta: Momentum, 2010), vi.

${ }^{8}$ Jaerock Lee, Pesan Salib (Yogyakarta: ANDI, 2002), 143.

${ }^{9}$ Perkataan Yesus berdasarkan ayat-ayat yang dikutip dari Alkitab Terjemahan Baru (Jakarta: Lembaga Alkitab Indonesia, 2009)
} 
Inilah yang disebut dengan tujuh ungkapan terakhir Yesus di kayu salib. ${ }^{10}$ Untuk mengerti apa yang sebenarnya terjadi di Golgota, haruslah kita melihat ke dalam hati dan pikiran Tuhan Yesus sendiri, bagaimana tanggapan-Nya terhadap peristiwa itu. Hal ini dapat kita temui dalam ketujuh ucapan yang Ia keluarkan, tatkala Ia tergantung di atas salib, sebelum pancaindra-Nya diselubungi tirai kematian. Ucapan-ucapan ini laksana jendela, yang melaluinya kita dapat melihat apa yang di pikiranNya. ${ }^{11}$

Ungkapan Yesus di Salib begitu sulit dan menimbulkan banyak pertanyaan serta pandangan yang berbeda. Satu alasan dari keluhan bahwa ungkapan Yesus itu sulit adalah karena Dia membuat pendengarNya berpikir. Bagi sebagian orang berpikir merupakan suatu pekerjaan yang sulit dan tidak enak, terutama bila menyangkut penilaian kembali yang kritis dari prasangka dan pendirian yang kuat, atau bila menyangkut tantangan terhadap konsensus pemikiran zaman sekarang. ${ }^{12}$

\section{Makna Tujuh Ungkapan Yesus Di Salib}

Peristiwa kematian Tuhan Yesus Kristus di atas kayu salib karena dosa-dosa seluruh isi dunia mempunyai makna teologis yang tak terkira pentingnya. Ia hidup dan mati, tidak sama seperti orang lain yang pernah hidup dan mati. ${ }^{13}$ Dia tidak hanya menyingkirkan kuasa surgawi-Nya dan turun ke dunia dalam tubuh manusia, melainkan Dia juga menjadi Allah sepenuhnya dan manusia sepenuhnya. ${ }^{14}$ Bentuk-bentuk penderitaan, baik secara jasmani maupun psikis menandakan bahwa Yesus Kristus mengalami penderitaan yang sangat mengerikan yang hanya sekali berlangsung dalam sejarah dunia. ${ }^{15}$ Tujuh ungkapan-Nya di atas kayu salib bukan menyatakan kegagalan atau kekalahan, melainkan bukti kemenangan-Nya atas kuasa dosa. Melalui penyaliban dan kematian-Nya, kuasa maut dikalahkan (1 Kor. 15:54-57). PengorbananNya dimaksudkan untuk menyelamatkan manusia yang berdosa dari ketidakberdayaannya terhadap kuasa dosa yakni maut. Ia rela datang memberikan nyawa-Nya untuk menjadi tebusan bagi banyak orang.

Menurut penjelasan Stephen Tong, dalam bahasa Indonesia ada satu kalimat pembukaan yang tidak diterjemahkan ke dalam ayat tersebut,

\footnotetext{
${ }^{10}$ Jaerock Lee, Pesan Salib (Yogyakarta: ANDI, 2002), 143.

Il James M. Stalker, Sengsara Tuhan Yesus (Jakarta: Yayasan Komunikasi Bina Kasih, 2008), 128.

${ }^{12}$ F. F. Bruce, Ucapan Yesus Yang Sulit (Malang: Literatur SAAT, 2007), viii.

${ }^{13}$ John F. Walvoord, Yesus Kristus Tuhan Kita (Surabaya: YAKIN, 1969), 118-119.

${ }^{14}$ Mark A. Marinella, Yesus yang Disalib Bagiku (Yogyakarta: Andi, 2009), xxx.

${ }^{15}$ Sostenis Nggebu, Napak Tilas Jejak-Jejak Yesus (Bandung: Kalam Hidup, 2004), 194.
} 
yaitu kalimat, "pada saat itu Yesus berkata ..." Ada tiga hal yang ditekankan olehnya, yaitu: Saat paling lelah secara fisik, saat paling sengsara, dan saat paling sendiri. ${ }^{16}$ De Kamp mencoba menggambarkan penderitaan Yesus dengan sebuah pernyataan, "Selama berjam-jam, Dia bagaikan segumpal daging mentah yang tergantung di atas kayu salib." ${ }^{17}$ Rasa sakit yang dialami semakin parah pada setiap gerakan dan setiap tarikan napas. Angin sepoi-sepoi pun dapat menyebabkan sakit yang luar biasa. BibirNya pecah, mulut dan tenggorokan-Nya kering sampai Ia tidak dapat menelan. Suara-Nya begitu serak sampai ia tidak bisa berbicara. ${ }^{18}$

Indi Chandra menjelaskan bahwa dengan kondisi seperti Yesus, seseorang dapat dipastikan segera mengalami kondisi shock hipovolumik (kehabisan darah), maupun shock neurogenic (rasa sakit yang tak tertahankan). ${ }^{19}$ Dalam kondisi demikian, meskipun sudah nyaris tidak dapat berbicara lagi, Tuhan Yesus mengucapkan tujuh ungkapan salib yang sangat terkenal hingga saat ini. Ketujuh ungkapan tersebut adalah sebagai berikut.

Tabel 1. Tujuh Ungkapan Yesus di Salib

\begin{tabular}{|c|c|c|c|c|c|}
\hline \multicolumn{6}{|c|}{ Tujuh Ungkapan Yesus di Salib } \\
\hline & & Matius & Markus & Lukas & Yohanes \\
\hline 1 & $\begin{array}{c}\text { "Ya Bapa, ampunilah } \\
\text { mereka sebab mereka tidak } \\
\text { tahu apa yang mereka } \\
\text { perbuat.?" }\end{array}$ & & & $23: 34$ & \\
\hline 2 & $\begin{array}{l}\text { "Hari ini juga engkau akan } \\
\text { ada bersama-sama dengan } \\
\text { Aku di dalam Firdaus" }\end{array}$ & & & $23: 43$ & \\
\hline 3 & $\begin{array}{l}\text { "Ibu, Inilah anakmu! ... } \\
\text { Inilah ibumu!" }\end{array}$ & & & & 19:26 \\
\hline 4 & $\begin{array}{c}\text { "Allahku, Allahku, } \\
\text { mengapa Engkau } \\
\text { meninggalkan Aku?" }\end{array}$ & $27: 46$ & 15:34 & & \\
\hline 5 & "Aku Haus!" & & & & $19: 28$ \\
\hline 6 & "Sudah Selesai" & & & & 19:30 \\
\hline 7 & $\begin{array}{c}\text { "Ya Bapa, ke dalam tangan- } \\
\text { Mu Kuserahkan nyawa- } \\
\text { Ku." }\end{array}$ & & & $23: 46$ & \\
\hline
\end{tabular}

${ }^{16}$ Stephen Tong, 7 Perkataan Salib (Jakarta: Momentum, 2010), 5.

${ }^{17}$ Wilkin van De Kamp, Tujuh Mujizat Salib Golgota (Malang: Gandum Mas, 2010), 155.

${ }^{18}$ Ibid., 155.

${ }^{19}$ Indi Chandra, Pilihan Anda Sudah Tepat (Malang: Gandum Mas, 2008). Dikutip oleh Jonar Situmorang, Via Dolorosa Membawa Kemenangan, 151. 


\section{Makna Teologis Tujuh Ungkapan Salib}

\section{Ungkapan Pertama: Ucapan Pengampunan}

Yesus berkata: "Ya Bapa, ampunilah mereka sebab mereka tidak tahu apa yang mereka perbuat." (Lukas 23:34).

\section{Posisi Allah sebagai Bapa}

Yesus memanggil Allah sebagai Bapa. Ini menyatakan hubungan kepemilikan Yesus kepada Allah. Yesus mengajarkan dalam Matius 6:9 mengenai doa Bapa kami. Dalam doa ini Ia mengajarkan dan menyatakan bahwa Allah adalah sosok yang dekat seperti halnya seorang Bapa. Ditegaskan lagi dalam kalimat selanjutnya dikuduskanlah nama-Mu. Secara harfiah sesuai dengan kebudayaan Yahudi, frasa "nama-Mu" pada zaman Yesus memiliki arti seluruh kepribadian Allah. Jadi, sebutan Bapa menyatakan keseluruhan kepribadian Allah.

Yesus adalah pengantara antara manusia dengan Allah. Yesus menyatakan bahwa Ia adalah jalan menuju Bapa dan melalui diri-Nya, manusia dapat mengenal Bapa (Yoh. 14:6-7). Filipi 2 memberitahukan bahwa jalan menuju salib merupakan puncak ketaatan Yesus sebagai Anak Bapa Surgawi. ${ }^{20}$ Hubungan yang begitu intim dan unik serta tidak ada bandingnya, tidak bisa digantikan oleh orang lain, ditunjukkan oleh Yesus untuk memberikan makna bahwa melalui peran Yesus sebagai Anak, mereka yang bertobat dan percaya kepada-Nya diangkat menjadi anak-anak Allah. Diangkat menjadi anak-anak Allah secara harfiah dalam bahasa Yunani menggunakan satu kata yang terjemahannya "pengangkatan anak-anak laki-laki". Kata tersebut adalah istilah dalam hukum Romawi yang menunjukkan bahwa pengangkatan orang Kristen sudah sah secara hukum dan semua dianggap laki-laki, karena dalam kebudayaan mereka hanya anak laki-laki saja yang berhak mendapat warisan. Sebagai Bapa, Allah sanggup memelihara, menjamin dan memimpin kehidupan. Dengan demikian Allah menjadi Bapa yang ideal bagi semua umat manusia (Ef. 3:14-15).

\section{Allah Memiliki Otoritas untuk Pengampunan Dosa}

Ucapan pengampunan, "ampunilah mereka" menandakan bahwa massa yang menonton di bukit Golgota adalah orang-orang berdosa. Yesus yang dihukum mati tidak bersalah. Massa tersebut meludahi dan mengejek Yesus, tetapi Ia tidak pernah membenci, melainkan mengasihi dan mengampuni mereka. ${ }^{21}$ Seruan Yesus menyatakan bahwa satu-satunya jalan untuk memperoleh pengampunan dosa ialah hanya dari Allah.

\footnotetext{
${ }^{20}$ G. Bingham, 7 Sabda Salib (Bandung: Kalam Hidup, 2003), 8.

${ }^{21}$ Bingham, 8.
} 
Beberapa penulis Alkitab mengemukakan bahwa pengampunan dosa hanya boleh dan dapat dilakukan oleh Allah. Dalam Markus 1:4, Yohanes mengakui hak Allah untuk mengampuni, ia menyerukan, "Bertobatlah dan berilah dirimu dibaptis dan Allah akan mengampuni dosamu." Pemazmur juga menyatakan hal yang sama bahwa pengampunan hanya dari Allah (Mzm. 130:4). Yesaya memberikan pandangannya bahwa Allah memberikan pengampunan dengan limpahnya (Yes. 55:7). Tetapi Yesus juga dalam pengajaran dan pelayanan-Nya menyatakan bahwa Ia dapat mengampuni dosa (Mrk. 2:112; Luk. 7:36-50). Hal tersebut menjelaskan bahwa Yesus adalah Allah yang memiliki hak untuk mengampuni dosa. Dia berkata, "Tetapi supaya kamu tahu, bahwa di dunia ini Anak Manusia berkuasa mengampuni dosa" (Mat. 9:6). Namun, suatu hal yang menarik bahwa Yesus di atas kayu salib yang mungkin seharusnya mengatakan bahwa, "dosa-dosamu sudah diampuni," karena memang Dia memiliki hak tersebut, malahan melakukan hal yang sebaliknya yaitu Dia berdoa kepada Bapa untuk pengampunan mereka. Mengapa Yesus melakukan hal tersebut? Apakah Dia tidak dapat mengampuni? Ataukah ada alasan lain Dia melakukan hal itu? Untuk menjawab pertanyaan tersebut orang Kristen harus melihat dari sudut padang Yesus Kristus di kayu salib yang bertindak sebagai perantara dan sebagai Imam yang mewakili manusia di hadapan Allah.

Terlepas dari semua itu, Dia tidak hanya berdoa bahwa mereka dapat diampuni tetapi Dia memberi mereka sebuah pengampunan! Mereka yang tidak mempunyai keberanian untuk melepaskan dari tuduhan, merekalah yang berseru dengan keras, "Biarlah darah-Nya ditanggungkan atas kami dan atas anak-anak kami!" (Mat. 27: 25). Dia yang dicambuk dan disalibkan oleh mereka, tetapi Dia mengampuni mereka. Dia berkata: "sebab mereka tidak tahu apa yang mereka perbuat" (Luk. 23:34). Betapa ajaib Tuhan dalam kasih-Nya yang mendalam. Dia tidak bersegera untuk menghukum mereka; Dia tidak membalas dendam atau undur dari mereka. Kasih-Nya untuk mereka adalah baik; Dia meminta pengampunan; Dia membebaskan mereka dari tuduhan; Dia membela mereka di hadapan Bapa surgawi, dan menyatakan bahwa dosa mereka hanya karena ketidaktahuan mereka. ${ }^{22}$

\section{Dosa Membutakan Mata Manusia Terhadap Kebenaran}

Ungkapan, "Mereka tidak tahu" berarti mereka itu termasuk: orang Yahudi, Yunani, dan Romawi yang tidak mengetahui siapakah Yesus itu. Mereka hanya mengetahui Yesus adalah orang benar bukan orang yang

\footnotetext{
${ }^{22}$ Shenouda III, H. H. Pope. The Seven Words of Our Lord On The Cross (Dar El Tebaa El Kawmia, 1991, 14.
} 
paling benar. Dosa telah menggelapkan mata manusia sehingga tidak dapat melihat kebenaran dan tidak dapat menyelidiki apakah Yesus benar-benar adalah Anak Allah (1 Kor. 2:6-8). ${ }^{23}$ Dosa membutakan dan menggelapkan hati dan pikiran manusia (Rom. 1:21).

Dosa adalah setiap pikiran, kata-kata, atau tindakan yang dengan sadar tidak taat kepada kehendak Allah dan dalam arti tertentu menolak kebaikan dan cinta ilahi. ${ }^{24}$ Dosa merusak dan menjauhkan manusia dari Allah dan hukuman Allah terhadap dosa ialah maut (Rm. 6:23a), sebab Allah yang adil tidaklah sekali-kali membebaskan manusia yang berdosa dari hukuman (Kel. 34:7). Maut berarti terpisah dengan Allah untuk selama-lamanya. Menurut Bridges, dosa diibaratkan sebagai tumor ganas spiritual dan moral yang jika dibiarkan, dapat menyebar ke seluruh keberadaan hati dan mencemari setiap bagian hidup. ${ }^{25}$

Yesus datang dan mati di kayu salib supaya manusia disadarkan dan diselamatkan dari pengaruh dan akibat dosa. Melalui Roh-Nya yang Kudus, manusia yang berdosa dicelikkan dan disadarkan akan dosa, kebenaran dan penghakiman (Yoh. 16:8) dan melalui Yesus, manusia berdosa dapat diselamatkan.

\section{Ungkapan Kedua: Ucapan Keselamatan}

"Hari ini juga engkau akan ada bersama-sama dengan Aku di dalam Firdaus" (Lukas 23:43).

\section{Yesus Adalah Mesias}

Lukas 23:39-41 menggambarkan percakapan antara Yesus Kristus dan dua penjahat ketika disalibkan menjelang kematian mereka di bukit Golgota. Berikut sekilas gambaran sikap dan situasi saat itu: (1) Penjahat I menyebut Yesus sebagai "Kristus" dengan sikap menghujat. (2) Penjahat II menyebut "Yesus" dan menggunakan kata "kerajaan". Istilah "kerajaan" dipakai dalam nubuatan Perjanjian Lama (Dan. 7:13-14). Dengan menggunakan istilah ini, si penjahat mengakui Yesus sebagai seorang raja. Kelihatannya ia telah bertobat ketika memandang Yesus sambil mendengar sabda pertama-Nya. Selain itu, ia percaya bahwa Yesus adalah Mesias. Kebenaran identitas Yesus adalah Allah yang menyelamatkan jelas terungkap bagi penjahat. ${ }^{26}$ Yesus menyambut penjahat itu karena ia mau bertobat dan percaya kepada-Nya.

\footnotetext{
${ }^{23}$ Bingham, 8.

${ }^{24}$ Gerald O’ Collins, Edward G. Farrugia, Kamus Teologi (Yogyakarta: Kanisius, 2003), s.v. "dosa”, 59.

${ }_{25}^{25}$ Jerry Bridges, Dosa-dosa Yang Dianggap Pantas (Bandung: Pionir Jaya, 2009), 25.

${ }^{26}$ Bingham, 11.
} 
Dalam naskah-naskah Yahudi yang berbicara tentang Mesias atau figur mesianis, istilah Juruselamat tidak dipakai, tetapi ada gambaran umum tentang keselamatan, karena seorang figur mesias bertindak sebagai agen Allah dalam membebaskan Israel dari masalah dosanya, penindasan, penyakit, dan setiap jenis kehancuran, suatu kondisi pembuangan spiritual dari berkat-berkat penuh zaman yang akan datang. ${ }^{27}$

Lukas adalah penulis yang menyoroti profil Yesus sebagai Juruselamat dengan baik. Sebagai Juruselamat dunia yang tidak memandang ras atau kebangsaan, derajat, jenis kelamin, kekayaan atau usia. ${ }^{28}$ Yesus menjadi manusia supaya Dia dapat memasuki kondisi manusia dan menjadi wakil manusia untuk mencari dan menyelamatkan yang hilang di dalam diri manusia. ${ }^{29}$ Jawaban Yesus menegaskan bahwa Dia adalah Mesias dari Allah yang memiliki misi untuk membebaskan dan menjamin keselamatan umat-Nya. Jawaban Yesus mengandung makna bahwa Dia mengasihi dan mencari yang hilang serta memiliki otoritas dalam kehidupan manusia untuk menyelamatkan mereka dari kuasa maut. Secara tidak langsung, Yesus membenarkan tuduhan dan olokan yang ditujukan bagi-Nya sebagai Mesias, Anak Allah, Raja yang berkuasa.

\section{Pertobatan dan Keselamatan adalah Anugerah Allah}

Pertobatan adalah suatu tindakan yang harus dilakukan (Mrk. 1:4) dan membutuhkan pengakuan secara pribadi bahwa ia berdosa dan membutuhkan pengampunan (1 Yoh. 1:7-9), sebab jika tidak dilakukan maka akan binasa (Luk. 13:3). Pertobatan merupakan tindakan yang dilakukan dengan penuh kesadaran supaya dosa dihapuskan (Kis. 3:19) karena pertobatan membawa keselamatan (2 Kor. 7:10). Pertobatan bukanlah karena sesuatu yang murni berasal oleh manusia, tetapi karena semata-mata karena karya Allah yang bekerja dalam kehidupan manusia.

Hoekema menjelaskan bahwa pertobatan digambarkan sebagai karya Allah atau lebih baik dikatakan suatu karya yang dimampukan oleh Allah untuk dikerjakan oleh manusia. ${ }^{30}$ Alkitab dengan jelas mengajarkan bahwa manusia harus bertobatdan berbalik kepada Allah supaya memperoleh pengampunan. Meskipun demikian, Penjahat yang disalibkan tidak memiliki kesempatan untuk melakukan sesuatu bagi

\footnotetext{
${ }^{27}$ Leland Ryken, James C. Wilhoit, Tremper Longman III, Kamus Gambaran Umum (Surabaya: Momentum, 2011), s.v. "Yesus, gambaran tentang", 1234.

${ }^{28}$ John Stott, Kristus yang Tiada Tara (Surabaya: Momentum, 2008), 18.

${ }^{29}$ Ray C. Stedman, Petualangan Menjelajah Perjanjian Baru (Jakarta: Duta Harapan Dunia, 2003), 62.

${ }^{30}$ Anthony A. Hoekema, Diselamatkan oleh Anugerah (Surabaya: Momentum, 2008), 170.
} 
Tuhan. Tangan dan kakinya yang terpaku menjelaskan hal tersebut. Jadi, keselamatan yang diperoleh oleh penjahat yang bertobat ini semata-mata karena ia bertobat dan sungguh-sungguh percaya dan mengandalkan Yesus inilah iman ${ }^{31}$ yang menyelamatkan yang dianugerahkan kepada penjahat itu. Hoekema mendefinisikan iman yang menyelamatkan sebagai berikut:

Iman yang menyelamatkan dapat didefinisikan sebagai suatu respons terhadap panggilan Allah melalui penerimaan akan Kristus dengan keseluruhan pribadi yaitu dengan keyakinan yang pasti mengenai kebenaran Injil dan penyerahan yang penuh keyakinan pada Allah di dalam Kristus bagi keselamatan kita, disertai komitmen sejati kepada Kristus dan untuk melayani-Nya. ${ }^{32}$

Efesus 2:8-9 menyatakan bahwa, "Sebab karena kasih karunia kamu diselamatkan oleh iman; itu bukan hasil usahamu, tetapi pemberian Allah, itu bukan hasil pekerjaanmu: jangan ada orang yang memegahkan diri." Jadi pertobatan dan keselamatan yang diperoleh oleh perjahat tersebut merupakan Anugerah Allah.

\section{Firdaus Tempat yang Pasti Bagi Orang-Orang yang Meninggal di Dalam Tuhan}

Yesus menjanjikan kepada seorang penjahat yang bertobat di samping-Nya, bahwa Ia akan bersama dengannya di dalam firdaus. Pada dasarnya, Firdaus berarti "taman." Konsep firdaus berasal dari Taman Eden, tempat manusia pernah berjalan dan berbicara dengan akrab dengan Allah, Penciptanya. Taman Eden menjadi taman penuh kedamaian dan kepuasan sejati. Kehadiran Allah bersama manusia menjadi ciri khas taman itu. Hak untuk diam dalam taman ini diberikan kepada orang yang telah disucikan, dan orang yang berdosa tidak memilikinya. ${ }^{33}$

Dalam terjemahan bahasa Inggris, Firdaus diterjemahkan menjadi paradise yang berarti surga. Surga inilah yang dimaksud menjadi tempat kediaman akhir yang disiapkan Allah untuk orang-orang yang ditebusNya (Yoh. 14:1-6). Jadi firdaus yang dimaksud adalah surga yang merupakan tempat bagi mereka yang terberkati berada bukan tempat jiwa-jiwa yang terkutuk dibuang. Yesus memberi tahu semua orang

\footnotetext{
${ }^{31}$ Ibrani 11:6 menjelaskan sebab tanpa iman tidak seorangpun berkenan kepada Allah. Iman adalah sarana yang dengannya kita diselamatkan (Rom. 10:9), dan jalan menuju pengharapan yang pasti (Ibr. 1l:1). Ibid., 167.

${ }^{32}$ Ibid., 186.

${ }^{33}$ Bingham, 12.
} 
percaya yang telah bertobat bahwa mereka akan bersama-sama dengan Dia di tempat itu.

Jaminan hidup kekal yang dianugerahkan pada hari seseorang bertobat dan menerima Yesus menjadi Tuhan dan Juruselamat. ${ }^{34}$ Yohanes mencatat: "Sebab barangsiapa yang percaya kepada-Nya tidak binasa melainkan beroleh hidup yang kekal" (Yoh. 3:16). Kebenaran dan ketidakberubahan Allah di dalam Yesus Kristus menjamin kepastian orang percaya diselamatkan. ${ }^{35}$ Sebab apa yang telah difirmankan Allah dengan mulut-Nya, pasti dapat dan akan dilakukan-Nya.

Yesus bukan saja menjanjikan sebuah tempat dalam kekekalan, tetapi Dia juga berjanji untuk bersama-sama dengan mereka yang percaya kepada-Nya. Karena surga merupakan tempat yang kekal artinya persekutuan bersama dengan Kristus bersifat kekal bukan sementara. Inilah yang menjadi hal yang penting bagi orang percaya yakni bahwa mereka bukan saja memiliki kepastian hidup yang kekal di surga, tetapi juga kepastian bersekutu bersama-sama Yesus selamanya di sana.

\section{Ungkapan Ketiga: Ucapan Kasih}

"Ibu, Inilah anakmu! ... Inilah ibumu!" (Yoh. 19:26-27).

\section{Allah Mengasihi dan Memberikan Penghiburan yang Sejati}

Hati Tuhan Yesus tertuju kepada ibu-Nya. Di atas kesakitan-Nya sendiri, Dia merasakan kepedihan hati ibu-Nya. Seorang ibu seperti Maria selayaknya tidak tahan melihat penderitaan berat yang menimpa putranya. Maria juga sepertinya merasa seorang diri sebab kemungkinan besar Yusuf sudah lama meninggal dan anak-anaknya yang lain tidak percaya kepada Tuhan Yesus. ${ }^{36}$ Maria bukan hanya kehilangan seorang anak yang sangat dikasihinya, tetapi juga seorang yang menjadi tulang punggung kehidupannya. ${ }^{33}$ Tak dapat disangkali bahwa peristiwa kematian Yesus menimbulkan kekhawatiran, ketakutan, kesusahan dan juga kegelisahan bagi Maria yang ditinggalkan. Yesus yang mengetahui tugas sebagai seorang anak memahami apa yang seharusnya dilakukan ketika Ia akan meninggalkan Maria ibu-Nya, akan tetapi saat di kayu

\footnotetext{
${ }^{34}$ Stephen Tong, 35.

${ }^{35}$ John Owen, Jaminan Keselamatan Kristen (Surabaya: Momentum, 2005), 56.

${ }^{36}$ Wilkin van De kamp, 157.

${ }^{37}$ Yesus memulai pelayanan-Nya pada usia 30 tahun dan diperkirakan bahwa sebelum pelayanan-Nya Ia berprofesi sebagai tukang kayu untuk menafkahi keluargaNya. Yusuf diperkirakan sudah lama meninggal sehingga beban sebagai tulang punggung keluarga diemban-Nya. Hubungan-Nya dengan Kristuslah yang menyambung kehidupannya selama ini. Matthew Henry, Tafsiran Injil Yohanes 19-30 (Surabaya: Momentum, 2010), 1332.
} 
salib, posisi-Nya sudah bukan lagi sebagai anak Maria tetapi juga sebagai Juruselamat, oleh karena itu Yesus memanggil ibu-Nya dengan sebutan wanita (Yun.: gune). Sebutan ini berawal ketika perkawinan di Kana. Hal ini menandakan bahwa hubungan alami antara Dia dan ibunya sudah berubah. Dia bukan lagi putra ibunya, melainkan Anak manusia, Putra Allah. Maria harus memandang Tuhan Yesus dengan kacamata yang lain bahwa Tuhan Yesus adalah Penebusnya juga.

Ungkapan Yesus kepada Maria menunjukkan bahwa Allah peduli kepada penderitaan yang dialami oleh seorang yang kehilangan anak yang dikasihi. Dalam posisi-Nya sebagai Allah, Ia memberikan penghiburan dan pengharapan kepada Maria dengan menunjuk murid yang mengasihi dan dikasihi-Nya sebagai pengganti-Nya.

Yesus dalam penderitaan-Nya menjelang kematian mengetahui dan memahami kegelisahan yang dialami oleh Maria. Kemudian, Ia memberikan perhatian-Nya dengan menugaskan seseorang yang dikasihi-Nya (Yohanes) untuk memelihara Maria. Dan sejak saat itu, saat yang tidak akan pernah terlupakan itu, murid itu menerima dia di dalam rumahnya. ${ }^{38}$

\section{Hubungan yang Erat Dengan Allah Menghasilkan Hubungan Sesama yang Kuat dan Dekat}

Maria adalah seorang yang sangat mengasihi Yesus. Yohanes adalah murid yang begitu mengasihi Yesus sehingga ia disebut sebagai murid yang dikasihi. Yesus mempersatukan hubungan kedua orang yang mengasihi-Nya ke dalam sebuah ikatan keluarga yang tak terpisahkan. Inilah yang akan terjadi di dalam kehidupan orang-orang yang mengasihi Tuhan. Bingham menggambarkan hubungan itu sebagai berikut:

Hubungan vertikal yang kuat akan menghasilkan hubungan horizontal yang kuat dan dekat. Hubungan inilah yang dimaksud Yesus ketika Ia mengatakan, "Siapa ibu-Ku? Dan siapa saudara-saudara-Ku?" Lalu kataNya, sambil menunjuk ke arah murid-murid-Nya: "Ini ibu-Ku dan saudarasaudara-Ku! Sebab siapa pun yang melakukan kehendak Bapa-Ku di sorga, dialah saudara-Ku laki-laki, dialah saudara-Ku perempuan, dialah ibu-Ku" (Mat. 12:48-50). Mereka yang mengasihi Yesus, pasti akan menuruti segala perintah-Nya dan mereka akan disebut saudara (Yoh. 14:15) dan Allah akan melimpahkan kasih-Nya dan diam bersama mereka (Yoh. 14:23). Jadi, semua orang yang mengasihi Tuhan dipersatukan di dalam sebuah ikatan keluarga dalam Kristus Yesus. ${ }^{39}$

\footnotetext{
${ }^{38}$ Wilkin van De kamp, Tujuh Mujizat Salib Golgota, 158.

${ }^{39}$ G. Bingham, 7 Sabda Salib 14.
} 


\section{Ungkapan Keempat: Ucapan Penderitaan Rohani}

"Allahku, Allahku, mengapa Engkau meninggalkan Aku?" (Mat. 27:46; Mrk. 15:34).

\section{Yesus Menggantikan Manusia yang Berdosa}

Yesus berteriak sebagai manusia. Ia bukan berteriak, "Bapa-Ku!" seperti layaknya Anak Allah, melainkan, "Allahku!", seperti manusia biasa. Sepanjang masa, manusia yang berdosa telah berseru kepada langit, mencari Allah Pencipta dan Penyelamatnya, tetapi tidak menemukannya. Yesuspun berteriak demikian saat Ia disalib. Ia menyerukan jeritan batin manusia yang primitif.

Kesendirian Yesus mencapai puncak-Nya. Sekalipun Ia ditinggalkan seorang diri oleh orang-orang yang dekat dengan-Nya tetapi Ia tidak seorang diri karena Ia yakin Bapa selalu menyertai-Nya (Yoh. 16:32), namun pada saat ini Yesus mengalami masa yang paling gelap dalam hidup-Nya yakni ditinggalkan oleh Allah. ${ }^{40}$ Dalam keadaan ini, Yesus berjiwa sebagai pengganti manusia yang berdosa yang harus menerima cawan murka Allah. Yesus Kristus ditinggalkan, karena dosa telah memisahkan manusia dari Allah. ${ }^{41}$ Oleh karena kasih-Nya bagi manusia, Dia rela membiarkan hukuman Allah atas dunia ini ditimpakan atas diriNya dengan meminum habis cawan murka Allah yang penuh dosa manusia. Dia yang tidak mengenal dosa telah dibuat-Nya menjadi dosa karena manusia, supaya dalam Dia, manusia dibenarkan oleh Allah (2 Kor 5:21). Tetapi bagaimana mengetahui bahwa Kristus yang tidak berdosa dibuat berdosa? Dia yang benar dijadikan tidak benar karena manusia? (1 Pet. 3:18). Stephen Tong menjelaskan meskipun hal itu tidak dapat dimengerti, Alkitab mengajarkan bahwa hal itu harus diterima dengan iman. ${ }^{42}$

Yesus menggantikan manusia yang berdosa. Menurut Derek Prince dalam sebuah analisis dari Yesaya 53, di atas kayu salib terjadi sebuah pertukaran yaitu semua kejahatan karena pemberontakan manusia ditukar dengan semua kebaikan karena Yesus taat dan tidak berdosa. Hal ini meliputi: ${ }^{43}$

\footnotetext{
${ }^{40}$ Dosa mengakibatkan keterpisahan dengan Allah. Manusia yang berdosa tidak dapat bertahan di hadapan Allah yang Mahakudus. Upah dosa adalah kematian. Keterpisahan dan Kematian harus ditanggung oleh Yesus sebagai pengganti manusia yang berdosa.

${ }^{41}$ S. Zwemer, 43.

${ }^{42}$ Stephen Tong, 78.

${ }^{43}$ Derek Prince, The Exchange at The Cross (1989). Dikutip oleh G. Bingham, 7 Sabda Salib (Bandung: Kalam Hidup, 2003), 22.
} 
Tabel 2. Analisis Nubuatan Yesus Berdasarkan Kitab Yesaya 53

\begin{tabular}{|c|c|c|c|c|}
\hline \multirow{8}{*}{ Yesus } & Dihukum & \multirow{8}{*}{$\begin{array}{c}\text { Supaya } \\
\text { manusia } \\
\text { dapat }\end{array}$} & Diampuni & Ayat 4 \\
\hline & Dilukai & & Disembuhkan & Ayat 5 \\
\hline & Dijadikan berdosa & & Menjadi benar & Ayat 10 \\
\hline & Menemui maut & & Beroleh hidup & Ibr. $2: 9$ \\
\hline & Dijadikan kutuk & & Menerima berkat & Ef. $1: 3$ \\
\hline & Menjadi miskin & & $\begin{array}{l}\text { Menerima kelimpahan- } \\
\text { Nya }\end{array}$ & 2 Kor. $8: 9$ \\
\hline & Dipermalukan & & $\begin{array}{l}\text { Menerima kemuliaan- } \\
\text { Nya }\end{array}$ & 2 Kor. 3:18 \\
\hline & Ditinggalkan & & Diterima Allah & 2 Ptr. 1:11 \\
\hline
\end{tabular}

Dalam keadaan yang paling sulit, Yesus sudah menjalani dengan taat misi-Nya untuk menggantikan manusia yang berdosa. Yesus mencintai manusia sampai akhir. Yesus sudah mengalami satu pengadilan Ilahi dan satu kekejaman hukuman neraka yang seharusnya diterima oleh manusia yang berdosa. ${ }^{44}$ Jikalau Kristus tidak pernah ke situ, maka itu menjadi tempat bagi semua manusia berdosa. Inilah bukti cinta kasih Allah bagi manusia yang berdosa.

\section{Dosa Memisahkan Hubungan Antara Allah dan Manusia}

Teriakan Yesus memperlihatkan dahsyatnya dosa dan bagian yang harus ditanggung-Nya sebagai pengganti manusia yang berdosa. Dosa mengakibatkan pemisahan dengan Allah dan pemisahan ini ialah "maut" (Rm. 3:23). Kegelapan selama tiga jam menggambarkan kegelapan yang ada pada diri manusia akibat dosa. Kegelapan yang paling gelap sering dihubungkan dengan keadaan neraka (Mat. 25:30).

Inilah teriakan penderitaan rohani yang harus dialami Yesus sebagai pengganti manusia berdosa - teriakan dengan status sebagai orang berdosa. Dahsyatnya dosa tersirat dalam seruan Yesus ini dan menjelaskan bahwa dosa menghalangi dan memisahkan hubungan Allah dan manusia serta membuahkan kematian.

\section{Ungkapan Kelima: Ucapan Penderitaan Jasmani \\ "Aku haus!" (Yoh. 19:28)}

\section{Bukti Kemanusiaan Yesus Bahwa Dia adalah Manusia Sejati}

Rasa haus adalah salah satu sifat dasar manusiawi yang dimiliki manusia. Yesus adalah Allah sejati yang memiliki sifat-sifat Allah dan juga adalah manusia seutuhnya yang juga memiliki sifat-sifat manusia.

Yesus adalah Allah yang telah menyatakan diri-Nya dalam rupa manusia (1 Tim. 3:16). Hal ini sangat mustahil bagi manusia yang

\footnotetext{
${ }^{44}$ Stephen Tong, 82.
} 
pikirannya terbatas untuk mendefinisikannya secara ilmiah karena hanya Allah yang tahu (Mat. 11:27). Sementara itu, ada banyak hal tentang pribadi Kristus yang tidak dapat dimengerti dengan pemahaman manusia terutama adalah mengenai keilahian-Nya dan kemanusiaanNya.

Tuhan Yesus bukanlah manusia ilahi atau Allah manusiawi; Dia adalah Allah-manusia. Ia lahir dari perawan Maria (Mat. 1:23; Gal. 4:4) dan hal ini telah dinubuatkan oleh nabi Yesus (Yes. 7:14). Yohanes menyatakan hal ini secara lebih teologis, yaitu bahwa Firman yang ilahi dan kekal telah menjadi daging, dan bahwa Allah telah "diam" di antara manusia (Yoh. 1:l; 14). ${ }^{45}$ Paulus juga menjelaskan apa yang dimaksudkannya dengan Kristus mengosongkan diri-Nya dengan mengambil rupa seorang hamba bukanlah sekadar masalah pengesampingan penggunaan atribut ilahi, tapi lebih tentang perendahan diri Anak Allah dengan mengambil rupa manusia; bahkan dalam "rupa seorang hamba." (Fil. 2:6-8; 2 Kor. 8:9). Hal itu dinyatakan dengan kerelaan-Nya menempatkan diri untuk senantiasa taat. Orang Kristen juga harus hidup dengan rendah hati sebagai seorang hamba, mengikuti teladan Kristus. Spurgeon pernah berkata mengenai kemanusiaan Yesus:

Bagaimana Ia adalah sepenuhnya manusia; Ia adalah sungguh, "tulang dari tulang kita dan daging dari daging kita," karena Ia memikul penyakit kita... Yesus terbukti sebagai manusia sejati, karena Ia telah menderita kesakitan seperti yang dapat dialami manusia. Para malaikat tidak dapat menderita kehausan. Hantu [roh], tidak dapat menderita kehausan; namun Yesus sungguh menderita [dan Ia] mengalami kehausan pada tingkat yang luar biasa, karena ini adalah rasa haus menjelang kematian yang menghampiri Dia. Rasa haus itu disebabkan oleh habisnya darah, dan demam yang disebabkan oleh iritasi yang disebabkan oleh karena selama empat jam tergantung dengan penuh luka-luka yang sangat menyedihkan. ketika beban tubuh-Nya pada posisi terpaku tergantung menariknya ke bawah, dan luka-luka-Nya. Kesakitan yang luar biasa itu menyebabkan demam tinggi. Penderitaan itu menyebabkan mulut-Nya menjadi kering dan membuat kerongkongannya panas, sampai akhirnya Ia mengumumkan, dengan mengutip Mazmur dua puluh dua, "lidahku melekat pada langitlangit mulutku." 46

\footnotetext{
${ }^{45}$ Trivena Ambarsari, Seri Pelajaran Irecs: Kristologi (Surabaya: Momentum, 2012), 11.

${ }^{46}$ C. H. Spurgeon, The Shortest of the Seven Cries: The Metropolitan Tabernacle Pulpit,(Pilgrim Publications, 1972), 219-220, diakses 10 April 2014, http://www.rlhymersjr.com/Online_Sermons_Indonesian/2010/012410PM_ThirstOfJesu s.html
} 
Manusia dalam kemuliaannya kelak dikatakan tidak akan menderita lapar dan dahaga lagi, sebab Yesus, akan menggembalakan mereka dan akan menuntun mereka ke mata air kehidupan dan Allah akan menghapus segala air mata dari mata mereka (Wahyu 7:16-17). Itulah sebabnya, dalam segala hal Yesus harus disamakan dengan saudarasaudara-Nya, supaya Ia menjadi Imam Besar yang menaruh belas kasihan dan yang setia kepada Allah untuk mendamaikan dosa seluruh bangsa (Ibr. 2:17).

\section{Yesus Adalah Sumber Kepuasan Sejati}

Yesus mengundang manusia datang kepada-Nya supaya memperoleh air hidup. Tetapi kali ini, Ia berseru bahwa Dia haus. Dia yang memberi air hidup, tetapi mengalami kehausan. Penderitaan yang dialami-Nya di bawah terik matahari membuat-Nya haus.

Ketika Yesus dalam perjalanan-Nya melalui Samaria, dalam kondisi yang lelah Ia berkata kepada seorang wanita di sumur Yakub, "Berilah Aku minum." (Yoh. 4:7). Jadi tidak aneh, bila kemudian di akhir hidupNya yakni setelah dicambuk sampai setengah mati dan dipakukan di kayu Salib selama kurang lebih empat jam, kemudian Ia harus berkata, "Aku haus." Rasa haus-Nya menunjukkan kepada kita kemanusiaanNya. Ini adalah rasa haus seorang manusia, manusia sejati. ${ }^{47}$

Tidak ada seorang pun yang mampu mengerti kehausan macam apa yang dialami Kristus. Siksaan neraka digambarkan dengan rasa haus yang amat sangat, dikisahkan dalam Lukas 16, yakni ketika si pria kaya memohon-mohon setitik air untuk mendinginkan lidahnya. Rasa haus yang seganas itulah yang sudah akan menjadi hukuman bagi manusia selamanya, jika saja Kristus tidak menanggung derita bagi manusia. ${ }^{48}$ Keadaan haus yang tidak dapat dibayangkan ini harus dialami oleh Kristus agar Ia dapat menjadi air hidup yang sesungguhnya bagi mereka yang datang kepada-Nya. Yesus rela mengalami haus yang luar biasa supaya manusia yang datang kepada-Nya tidak akan haus lagi untuk selama-lamanya.

Ini merupakan seruan kehausan yang menghentikan segala kehausan. Barangsiapa haus, hendaklah ia mengambil dari air kehidupan (yaitu Kristus) dengan cuma-cuma. ${ }^{49}$ Pernyataan "Aku haus" adalah seruan penderitaan yang harus dialami oleh Yesus untuk menebus manusia dari kuasa dosa yang menyiksa dan membinasakaan.

${ }^{47}$ R. L. Hymers, Rasa Haus Yesus di Kayu Salib (Baptist Tabernacle of Los Angeles, 2010), diakses 10 April 2014, http://www.rlhymersjr.com/Online_Sermons_Indonesian/2010/012410PM_ThirstOfJesu s.html

${ }^{48}$ Matthew Henry, Tafsiran Injil Yohanes 12-21, 1335-1336.

${ }^{49}$ Stephen Tong, 107. 
Penderitaan yang dialami-Nya bukan karena semata-mata Ia ingin menderita, tetapi karena kehendak Allah yang telah menetapkan penderitaan itu sebagai tujuan kedatangan-Nya. Tujuan kedatangan-Nya adalah supaya semua orang yang datang kepada-Nya memperoleh keselamatan dan pengharapan. Ia adalah sumber air kehidupan yang memberikan kelegaan dan kepuasan sejati bagi mereka yang datang kepada-Nya.

\section{Ungkapan Keenam: Ucapan Kemenangan}

"Sudah selesai" (Yoh. 19:30).

\section{Kemenangan Total: Rencana Allah Terhadap Penebusan Manusia Digenapi}

Ungkapan "sudah selesai" menjadi seruan kepada Allah dan manusia dan juga diri-Nya sendiri. Yesus memberitahukan diri sendiri bahwa Dia sudah berhasil. Jelas pula seruan ini diperuntukkan bagi para penguasa kegelapan bahwa mereka telah kalah total dan dalam pengadilan Allah. Mereka tinggal menunggu waktunya (pada hari terakhir) untuk diberi hukuman, yaitu maut. ${ }^{50}$

Dalam bahasa aslinya (Yunani), "selesai" mengandung konsep telos (akhir) dan kairos (waktunya Tuhan) sehingga secara keseluruhan berarti waktu yang direncanakan Allah. ${ }^{51}$ Yesus selalu menerima tugasNya dalam konteks rencana dan waktu Allah.

Yesus pernah berkata: "Makanan-Ku ialah melakukan kehendak Dia yang mengutus Aku dan menyelesaikan pekerjaan-Nya." (Yoh. 4:34). Yesus mempunyai pekerjaan besar dan berat untuk diselesaikan dan sekaligus juga sangat menderita dalam usaha penyelesaiannya. Mungkin hal utama yang muncul dalam pikiran-Nya ketika Ia berkata, "Sudah Selesai" ialah semua yang diberitakan lebih dulu di dalam PL sudah digenapi.

Yesus membuat sebuah Perjanjian Baru antara Allah dan manusia yang melibatkan: $^{.2}$

1. Kuasa maut dilumpuhkan dan Iblis dikalahkan (Ibr. 2:14).

2. Dosa manusia yang percaya kepada-Nya dilempar jauh (Mikha 7:19).

3. Kedatangan kerajaan ilahi-Nya (Roma 14:9).

4. Orang percaya diangkat menjadi anak-anak sang Raja dalam persekutuan dengan Roh Kudus (Gal. 4:4-6).

Tugas-Nya untuk memuliakan Allah di bumi sehingga Allah dikenal oleh manusia (Yoh. 17:4). Bersamaan dengan itu juga merupakan tugas

\footnotetext{
${ }^{50}$ Bingham, 27.

${ }^{51}$ Ibid., 27.

${ }^{52}$ Ibid., 28.
} 
untuk manusia demi Allah. Ia melakukan tugas-Nya sampai kematianNya di kayu salib sehingga pintu surga sekarang terbuka bagi semua orang.

\section{Jalan Keselamatan yang Disediakan Allah Melalui Karya Kristus Telah Sempurna}

Bentuk perfek digunakan dalam kata teleos mengandung pengertian bahwa apa yang sudah dilakukan oleh Yesus benar-benar sudah digenapi dan sempurna, tanpa perlu adanya penambahan apapun di dalamnya. Seperti halnya penggunaan (.) titik dalam sebuah kalimat. Inilah Injil tentang salib yaitu oleh kematian Kristus, tercapailah sudah tujuan kedatangan-Nya ke dunia. Melalui perkataan ini, Yesus menyatakan bahwa semua konsekuensi dosa manusia telah Ia selesaikan. Kesalahan kita sudah dibereskan, pendamaian antara Allah dan manusia sudah diwujudkan. ${ }^{53}$ Apa yang dikatakan-Nya itu, Dia katakan dengan penuh sorak-sorai dan menyatakan kemenangan total. Karena Kristus yang taat maka barangsiapa menerima Kristus akan diterima oleh Allah dan tidak ada seorangpun yang ditolak. Karena ketaatan Kristus, maka setiap orang yang mau datang kepada Kristus memiliki pengharapan hidup kekal. $^{54}$

Yesus melaksanakan semua hal ini, Ia telah mempersatukan bumi ini. Melalui Yesus, segala berkat dapat mengalir dan hasil ciptaan-Nya termasuk manusia, diperbarui. Dengan seruan-Nya "sudah selesai", Yesus membuat sebuah peristiwa terbesar setelah pada awal zaman menciptakan bumi/alam semesta. ${ }^{55}$ Tetelestai adalah sebuah kata yang merampungkan segalanya dan penuh penghiburan.

\section{Ungkapan Ketujuh: Ucapan Penyerahan}

"Ya Bapa, ke dalam tangan-Mu Kuserahkan nyawa-Ku" (Luk. 23:43).

\section{Segala Sesuatu Adalah Milik Allah dan di Bawah Kuasa-Nya}

Ucapan Yesus yang terakhir sebelum meninggal adalah kutipan dari Mazmur 31:6. Ia menambahkan sesuatu pada bagian permulaan dengan ungkapan "Bapa." kata itu tidak ada dalam mazmur dan tidak digunakan oleh Pemazmur. Yesus memberikan kedalaman arti yang baru dalam ayat tersebut dan memberikan kesadaran baru mengenai Allah kepada dunia.

Ungkapan pertama dan terakhir, diawali dan diakhiri dengan panggilan "Bapa". Yesus tetap fokus pada hubungan-Nya dengan Bapa. Ia

\footnotetext{
${ }^{53}$ Jonar Situmorang, 255.

${ }^{54}$ Stephen Tong, 121.

${ }^{55}$ Bingham, 29.
} 
tidak terpengaruh dengan hubungan lainnya karena jelas bahwa apa yang Ia kerjakan adalah menjalankan kehendak Allah Bapa.

"Ya Bapa, ke dalam tangan-Mu Kuserahkan nyawa-Ku" bukanlah pernyataan kekalahan, melainkan bentuk penyerahan diri secara total kepada Bapa. Yesus percaya sepenuhnya dengan menyerahkan nyawaNya kepada Bapa-Nya. Ketika Dia menyerahkan nyawa-Nya kepada Tuhan, Dia memposisikan diri-Nya sebagai manusia. Sebagai pengantara, Dia menjadi contoh bahwa manusia harus menyerahkan hidupnya kepada Allah. Kejadian ini juga merupakan salah satu bukti bahwa Yesus sebagai manusia, benar-benar mati. Pengalaman sebagai manusia sampai pada puncaknya ketika Dia harus mati dengan disalibkan. Dengan kematian Yesus, kuasa maut dikalahkan (1 Kor. 15:57) dan dalam kematian Yesus di kayu salib, orang percaya dapat melihat pemeliharaan Allah atas diri-Nya.

Yesus pernah berkata tentang nyawa-Nya, "Aku berkuasa memberikannya dan berkuasa mengambilnya kembali." dan Yesus menjelaskan "Tidak seorang pun mengambilnya dari pada-Ku." (Yoh. 10:18). Berarti tidak ada seorang pun baik manusia, penguasa dunia, utusan kegelapan termasuk Iblis, berkuasa atas nyawa Yesus. Ia tetap Tuhan atas segala hal dan tidak ada yang dapat menang atas Dia. ${ }^{56}$ Meskipun demikian, Ia tetap tunduk kepada otoritas Bapa yang berkuasa atas segala sesuatu. Ungkapan Yesus ini mengajarkan orang percaya untuk menyerahkan seluruh hidup kepada Allah karena segala sesuatu adalah milik Allah dan di bawah kekuasaan-Nya.

\section{Yesus Membuka Jalan yang Baru dan Hidup yang Baru}

Matius dan Markus menuliskan ketika Yesus menghembuskan napas-Nya yang terakhir, maka seketika itu juga tabir atau tirai yang menutup jalan masuk ke ruang mahakudus dalam Bait Suci terbelah dua. Tabir adalah pemisah antara tempat kudus dan mahakudus (bdg. 2 Taw. 3:14; Ibr. 6:9; 10:19-20).Terbelahnya tabir merupakan tanda bahwa jalan menuju kepada Allah telah terbuka dan tanda bahwa hadirat Allah terbuka bagi mereka yang percaya. Setiap orang percaya memiliki hidup yang baru dalam persekutuan dengan Bapa melalui jalan yang telah dibuka oleh kematian Kristus.

Oleh darah Yesus maka orang percaya sekarang dengan penuh keberanian dapat masuk ke dalam tempat kudus, karena Ia telah membuka jalan yang baru dan yang hidup bagi kita melalui tabir, yaitu diri-Nya sendiri, dan kita mempunyai seorang Imam Besar sebagai Kepala rumah Allah.

\footnotetext{
${ }^{56}$ G. Bingham, 7 Sabda Salib, 31.
} 


\section{Implikasi Praktis Tujuh Ungkapan Yesus Di Salib Bagi Kehidupan Orang Kristen}

\section{Allah Adalah Bapa Bagi Setiap Orang yang Telah Ditebus}

Yesus memperkenalkan Allah sebagai Bapa dan Ia menyatakan hubungan-Nya dengan Allah bagaikan seorang bapa dengan anaknya. Yesus senantiasa memanggil Allah sebagai Bapa dalam setiap doa-Nya. Melalui peran Yesus sebagai Anak, orang Kristen dapat memandang Allah sebagai seorang Bapa dan juga dapat diterima menjadi anak Allah (Gal. 4:4-6).

Makna praktis dalam kehidupan sebagai pengikut Kristus ialah bahwa setiap orang percaya diberikan hak istimewa untuk memanggil Allah sebagai Bapa karena telah ditebus oleh Yesus melalui ketaatan dan pengorbanan-Nya di kayu salib. Orang Kristen dapat datang kepada Allah dengan penuh kehormatan dan kepercayaan selayaknya seorang anak terhadap ayahnya. Posisi sebagai seorang anak juga adalah sebagai ahli waris, yang mewarisi segala berkat dan kemuliaan yang telah disediakan oleh Bapa.

Memanggil Allah sebagai Bapa dalam setiap doa memberikan pengharapan bagi orang percaya bahwa doa yang dinaikkan yang sesuai dengan kehendak-Nya pasti memiliki jawaban karena Ia adalah Bapa yang mengerti dan memahami segala kebutuhan dan pergumulan yang dihadapi oleh anak-anak-Nya dan menjawab tepat pada waktunya. Ia mendengar dan sanggup untuk menjawab karena Ia adalah Bapa yang Mahakuasa dan kekal serta hikmat-Nya dan kasih-Nya tidak dapat diselami.

\section{Doa Pengampunan Dosa Merupakan Hal yang Penting}

Doa Yesus dalam ungkapan-Nya yang pertama merupakan doa pengampunan dosa bagi musuh-musuh-Nya. Doa memohon pengampunan dosa merupakan hal yang penting. Yesus sendiri mengajarkannya dan bahkan melakukannya. Inilah teladan yang diberikan Yesus bagi setiap orang percaya.

Ketidakberdosaan Yesus tidak mengharuskan-Nya untuk berdoa memohon pengampunan bagi diri-Nya sendiri. Kalau diperhatikan, bagi orang yang hampir mati, berdoa untuk pengampunan dosanya merupakan hal yang begitu penting dan seharusnya menjadi fokus bagi orang tersebut karena sedikit lagi "menghadap Tuhan" dan harus mempertanggungjawabkan segala perbuatannya kepada Allah, tetapi tidak demikian dengan Yesus. Ia tidak harus, karena Ia sama sekali tidak berdosa dan tidak ada dosa yang perlu diakui sehingga doa pengampunan ini Ia tujukan bagi mereka yang berbuat jahat kepadaNya. 
Hal ini mengajarkan kepada setiap orang Kristen bahwa berdoa bagi pengampunan dosa penting, baik bagi diri sendiri maupun bagi orang lain. Mengapa? Karena setiap manusia merupakan makhluk yang tidak sempurna sehingga dalam perjalanan kehidupannya, secara khusus bagi orang Kristen pasti ada hal-hal yang tidak disadari dan diketahui terlebih dalam hal ketaatan kepada Tuhan. Dosa dapat terjadi baik disadari maupun tidak disadari. Inilah yang Yesus katakan bahwa "mereka tidak tahu apa yang mereka perbuat." Alkitab memberikan salah satu contoh bahwa jika seorang tahu bagaimana ia harus berbuat baik, tetapi ia tidak melakukannya, ia berdosa (Yakobus 4:17). Dosa karena tidak melakukan kebaikan seperti yang firman Tuhan katakan dapat menjadi dapat juga menjadi perbuatan yang secara tidak sadar terjadi. Oleh karena itu, Perlu dan penting dalam setiap doa orang Kristen untuk mengakui kesalahan dan memohon pengampunan dosa pribadi.

\section{Mengampuni dan Mendoakan Musuh}

Menurut Goldie Bristol dan Carol McGinnis, bagi orang Kristen tujuan dari pengampunan itu rangkap tiga: (1) untuk memulihkan atau menciptakan hubungan antara dua orang; (2) untuk mempererat kesatuan di dalam tubuh Kristus; dan (3) untuk mendemostrasikan kepada dunia kuasa dan kasih yang mengampuni dari Yesus Kristus. ${ }^{57}$ Hal praktisnya sebuah pengampunan itu bukan hal yang wajar, pengampunan itu mahal harganya, mengampuni itu bukan bersikap tidak acuh, mengampuni tidak berarti menyetujui yang salah, mengampuni adalah perbuatan kasih, mengampuni adalah langkah kehendak, mengampuni itu sangat berkuasa. ${ }^{58}$

Sebagai orang kristen wajib hukumnya untuk terus-menerus mendoakan orang-orang yang melakukan kesalahan. Yesus mati supaya manusia mengenal kebenaran dan dibersihkan oleh darah-Nya. Pengikut Kristus harus memahami dan mengampuni orang lain sebagai sambutan terhadap firman Allah ini sehingga dapat mengenal siapakah Bapa Kami yang ada di surga itu. ${ }^{59}$ Berdoa bagi musuh-musuh, dan bagi mereka yang membenci dan menganiaya haruslah dengan tidak membesar-besarkan kesalahan mereka seperti yang seharusnya dilakukan dengan kesalahankesalahan pribadi (mereka tidak tahu apa yang mereka perbuat, mungkin saja hal itu tidak disengaja). ${ }^{60}$ Sebagai pengikut Kristus,

\footnotetext{
${ }^{57}$ Goldie Bristol, Carol McGinnis, Haruskah Saya Mengampuni? (Bandung: Kalam Hidup, 1999), 49.

58 Ibid., 49.

${ }^{59}$ Bingham, 9.

${ }^{60}$ Matthew Henry, Tafsiran Matthew Henry: Injil Lukas 13-24, (Surabaya: Momentum, 2009), 854.
} 
kesungguhan berdoa kepada Allah Bapa untuk pengampunan dosa-dosa musuh, merupakan teladan yang diberikan dan dipertegas oleh Yesus sendiri sesuai dengan pengajaran-Nya untuk mengasihi musuh-musuh (Mat. 5:44-45). Pertanyaannya ialah jika Kristus mengasihi dan berdoa bagi musuh-musuh-Nya, bagaimana mungkin sebagai pengikut Kristus tidak mau mengasihi dan berdoa bagi musuh-musuhnya? Jadi kehidupan saling mengasihi Nampak dari tindakan seseorang untuk mendoakan sesama.

\section{Manusia Harus Bertobat dan Percaya Kepada Yesus Kristus}

Respons Yesus terhadap pertobatan seorang perampok yang disalibkan bersama-Nya mengajarkan kepada setiap kita bahwa ada anugerah pengampunan dan hidup yang kekal bersama Yesus di Firdaus yang disediakan bagi setiap orang yang sungguh-sungguh bertobat dan mau percaya kepada-Nya. Percaya dalam bahasa Yunani adalah pisteou artinya mempercayai, juga menyakinkan, menaruh kepercayaan, mempercayakan, menandakan. Jadi, percaya yang dimaksud bukan hanya sekedar percaya tetapi juga berserah sepenuhnya kepada Tuhan. ${ }^{61}$

Yesus pernah berkata bahwa akan ada sukacita yang besar di sorga karena satu orang berdosa yang bertobat lebih daripada banyaknya orang benar yang tidak memerlukan pertobatan (Luk. 15:7, 10). Tuhan Yesus masih menantikan mereka yang mau datang kepada-Nya, percaya dan bertobat. Dalam Roma 3:21-22 Allah telah menunjukkan jalan bagaimana manusia berbaik dengan Dia. Allah memungkinkan manusia berbaik dengan Dia, hanya kalau manusia percaya kepada Yesus Kristus. Allah akan menerima dan membebaskan manusia dari hukuman dosa dan hal tersebut hanya berlaku bagi semua orang yang percaya kepada Kristus. Dengan demikian, kematian membukakan pintu kekekalan bagi mereka yang bertobat dan percaya.

\section{Iman Kepada Yesus Membawa Keselamatan}

Kunci memperoleh hidup kekal ialah hanya dengan bertobat dan percaya kepada Yesus sebagai Tuhan dan Juru Selamat. Namun, perbuatan baik itu perlu dilakukan sebagai orang Kristen karena tiaptiap manusia kepunyaan Allah diperlengkapi untuk setiap perbuatan baik. Firman Tuhan juga mengatakan bahwa Iman tanpa perbuatan adalah mati (Yak. 2:17, 26). Melalui perbuatan baik, Allah dapat dimuliakan (1 Pet. 2:12). Tetapi, dalam keselamatan untuk memperoleh hidup kekal, perbuatan baik manusia tidak cukup untuk memenuhi tuntutan Allah yang sempurna. Perbuatan baik dan kesalehan manusia

\footnotetext{
${ }^{61}$ W. E. Vine, Vine's Expository Dictionary of New Testament Words, (Virginia: MacDonald, n.d.), 118.
} 
seperti kain kotor dalam pandangan Allah (Yes. 64:6). Yesus yang telah mati mewakili manusia yang berdosa telah menggantikan tuntutan perbuatan yang sempurna tanpa cela yang dikehendaki Allah sehingga hanya cukup dengan bertobat dan percaya Yesus, manusia memperoleh hidup kekal. Perbuatan baik merupakan bukti kesungguhan seseorang yang percaya kepada Tuhan. Perbuatan baik bukan merupakan syarat untuk memperoleh hidup kekal, tetapi merupakan rasa ungkapan syukur atas anugerah hidup kekal yang telah Tuhan Yesus berikan. Melalui Iman yang sungguh kepada Yesus sebagai Tuhan dan Juruselamat pribadi menjamin keselamatan hidup kekal dalam persekutuan dengan Yesus di surga.

\section{Tanggung Jawab Orang Percaya}

Yohanes adalah murid yang dikasihi Yesus dan yang juga sangat mengasihi Yesus. Hal tersebut terbukti dari sikap dan responsnya terhadap tanggung jawab yang diberikan Yesus untuk memelihara Maria sebagai ibunya sendiri.

Yohanes memberikan teladan bahwa setiap orang Kristen yang sungguh-sungguh mengasihi Tuhan memiliki tanggung jawab dari Tuhan untuk hidup dalam ketaatan dan kesetiaan melakukan firman Tuhan terlebih dalam mengasihi sesama sebagai saudara di dalam Tuhan. Hubungan yang saling mengasihi seperti mengasihi diri sendiri menjadi hal yang penting dalam kehidupan orang percaya. Mereka yang telah ditebus oleh Kristus memiliki tanggung jawab untuk saling mengasihi, mempedulikan, memperhatikan, menjaga, melindungi, dan menjadi berkat bagi sesama.

Seorang yang mengasihi Tuhan pasti akan melakukan perintah-Nya (Yoh. 14:23). Perintah Tuhan dilaksanakan bukan supaya memperoleh kasih karunia Tuhan, tetapi dilaksanakan karena cinta kasih kepada Tuhan. Orang percaya mengasihi karena Tuhan terlebih dahulu mengasihinya dengan memberikan Yesus sebagai bukti terbesar kasihNya bagi manusia. Jadi, dasar dari pelaksanaan tanggung jawab dari Tuhan adalah karena kasih kepada Tuhan bukan sebaliknya yakni supaya memperoleh kasih Tuhan.

\section{Risiko Dalam Mengikut Yesus}

Ada risiko bagi seseorang yang mengasihi Yesus. Maria yang mengasihi Yesus mengalami risiko dalam mengikuti panggilan Tuhan, yaitu bahwa Anak yang ia kasihi harus menderita dan mati dengan cara yang begitu tragis. Maria tetap pada pengharapannya saat pertama kali diberitahukan mengenai seorang juruselamat yang akan lahir dari rahimnya sendiri. "Sesungguhnya aku ini adalah hamba Tuhan; jadilah padaku menurut perkataanmu itu" (Luk. 1:38). Jiwanya tetap 
memuliakan Tuhan dan hatinya bergembira karena Allah, Juruselamatnya, dan segala keturunan menyebut ia berbahagia ... (ay. 4648). Di salib, Maria menyadari bahwa nubuatan Simeon mencapai puncak dalam penggenapannya, bahwa suatu pedang akan menembus jiwanya sendiri (ay.2:35). Pedang yang menembus jiwanya inilah yang terjadi melalui penderitaan dan kematian anaknya, Yesus.

Maria yang dengan taat dan patuh pada panggilan Tuhan untuk menjadi alat bagi pekerjaan-Nya sabar menanggung penderitaan dari mulanya, sekarang melihat dengan mata kepala sendiri penderitaan anaknya di kayu salib. Ibu siapa yang tega melihat anaknya demikian? tentu tidak ada. Semua ibu mengharapkan yang paling tebaik bagi anakanaknya. Seorang ibu sangat bangga jika melihat anak-anaknya sukses dan berhasil dalam masa depannya. Mariapun adalah seorang ibu yang memiliki pengharapan yang sama bagi anaknya, Yesus. Tetapi Ia menyadari meskipun Ia sangat mengasihi Allah, Yesus adalah Juruselamatnya dan Maria adalah manusia biasa sama seperti yang lain yang juga membutuhkan keselamatan dari Tuhan.

Penulis menanggapi dari perjalanan kehidupan Maria sebagai orang yang mengasihi Tuhan bahwa inilah suatu pedang bagi mereka yang mengasihi dan mengikuti Tuhan. Ada risiko dalam mengasihi dan mengikuti Yesus. Yesus pernah berkata setiap orang yang mau mengikut-Nya, harus menyangkal diri dan memikul salib dan mengikut Yesus. (Mat. 16:24; Mrk. 8:34; Luk. 9:23). Menyangkal diri dan memikul salib dan mengikut Yesus memerlukan pengorbanan dan kerelaan yang sungguh. Inilah risiko yakni pedang yang harus menembus jiwa setiap orang yang mengasihi Yesus yaitu menyangkal diri, memikul salib dan mengikut Yesus.

\section{Iman yang Teguh Sebagai Dasar Pengharapan}

Tuhan kita Yesus, sekalipun saat itu sedang ditinggalkan oleh BapaNya, tetap menganggap Bapa-Nya sebagai Allah-Nya. Allah-ku, Allah-ku, meski Engkau meninggalkan Aku, Engkau tetap Allah-Ku. Kristus adalah hamba Allah dalam melaksanakan pekerjaan penebusan. Dia berkewajiban memuaskan Allah, dan oleh Allah pula Dia disokong dan dimahkotai. Karena itulah, Dia tetap memanggil-Nya sebagai Allah-Nya, karena Dia kini sedang melakukan kehendak-Nya (Yes 49:5-9). Inilah yang menguatkan dan menyokong Dia, yaitu bahwa dalam penderitaanNya yang terdalam sekalipun, Allah tetaplah Allah-Nya, dan Dia bertekad untuk tetap berpegang pada kebenaran itu. ${ }^{62}$ Dia mempunyai iman yang teguh dan tabah terhadap Allah sekalipun Dia tahu Allah

\footnotetext{
${ }^{62}$ Matthew Henry, Tafsiran Matthew Henry: Injil Matius 15-28, (Surabaya: Momentum, 2008), 1498.
} 
telah meninggalkan-Nya. Di sinilah orang Kristen dapat memahami arti iman yang sesungguhnya yaitu bahwa iman bukan lagi merupakan iman yang dibangun di atas jawaban Allah yang jelas. Iman ialah mempercayai Allah sekalipun Allah tidak menjawab. Morris kemudian lebih mempertegas bahwa percaya kepada Allah meskipun Allah tidak menjawab adalah keyakinan yang paling dalam di antara segalanya. ${ }^{63}$ Iman adalah dasar dari segala sesuatu yang kita harapkan dan bukti dari segala sesuatu yang tidak kita lihat (Ibrani ll:1).

Sebagai pengikut Kristus ada kalanya suatu saat Allah terasa jauh, berdoa seakan-akan tidak didengar dan tidak ada jawaban karena dosa (Yes. 59:1-2). Manusia mungkin dapat berkata mengapa? Kepada Tuhan, keluhan terhadap kenyataan yang tidak dapat diterima. Ada kalanya Tuhan tidak menjawab doa, sebenarnya untuk mengajarkan kepada manusia arti sebuah pengharapan, iman dan kasih yang sesungguhnya. Terkadang Ia menjawab juga untuk menyatakan maksud-Nya yang mulia dan kesabaran-Nya yang besar, karena Ia menghendaki supaya jangan ada yang binasa, melainkan supaya semua orang berbalik dan bertobat (2 Pet. 3:9).

\section{Orang Kristen Sebagai Saluran Berkat}

Allah disebut sebagai "sumber air yang hidup". Melalui konsep ini, manusia diibaratkan menjadi anak sungai atau pipa layanan air minum untuk mendistribusikan dan mengalirkan berkat kepada orang lain. Orang Kristen tidak diciptakan untuk hidup mandiri, melainkan mempunyai ketergantungan kepada Allah, sebagai saluran dari Allah Sang Sumber (bdn. Yer. 2:13; Ams. 4:23; Kej. 12:3) ${ }^{64}$

Hal yang sama dapat digambarkan pada sebuah keran. Keran dapat berfungsi jika disambungkan dengan sebuah pipa saluran. Kenyataannya, manusia biasa hanya mengutamakan kemampuan diri sediri, tetapi Ia yang di salib menghayati Mazmur 69:3 karena Ia memandang kepada Allah. Selain itu, Ia juga memahami akibat dosa yang mengeringkan hati manusia. Yesus pernah berkata kepada wanita yang datang ke sumur tempat Yesus menunggu, "Barangsiapa minum air yang kuberikan kepadanya, ia tidak akan haus untuk selama-lamanya." (Yoh. 4:14). Akhirnya wanita itu menerima air kehidupan yang ada pada Yesus Kristus dan mengalirkannya kepada tetangga satu desanya. ${ }^{65}$

Tuhan Yesus dalam Matius 25:35-40 pernah berkata, "Ketika Aku haus, kamu memberi Aku minum." Kemudian orang-orang benar itu bertanya kepada Yesus, "Bilamanakah kami melihat Engkau haus dan

\footnotetext{
${ }^{63}$ Leon Morris, 85.

${ }^{64}$ Bingham, 24.

${ }^{65}$ Ibid., 25.
} 
memberi engkau minum? (Mat. 25:37). Lalu Ia menjawab, "sesungguhnya segala sesuatu yang kamu lakukan untuk salah seorang dari saudara-Ku yang paling hina ini, kamu telah melakukannya untuk Aku." Kapankah Yesus merasa haus, dan bagaimana memuaskan rasa haus Yesus itu? Yaitu dengan memberikan pertolongan dan perhatian terhadap sesama yang membutuhkan. Ini adalah hal yang menyenangkan hati Tuhan. ${ }^{66}$ James M. Stalker berkata, "Di mana saja saudara-saudara Tuhan Yesus menderita, atau duduk kesepian, berharap ada yang datang mengunjungi mereka, dan di mana saja mereka terbaring karena sakit dan memerlukan seseorang melawat dan mengambilkan air bila ia kehausan, di sanalah Kristus berkata, "Aku Haus!"67

Orang Kristen yang tanpa Kristus adalah orang Kristen yang kering dan juga tidak dapat menjadi berkat bagi orang lain karena hanya memikirkan diri sendiri, tetapi orang Kristen yang memiliki Kristus adalah orang Kristen yang hidup yang melalui kehidupannya menjadi saluran berkat bagi orang lain di sekitarnya. Mereka yang telah menerima sumber air kehidupan (Yesus) itu harus menjadi saluran berkat bagi orang lain. Matius 5:6 berkata, "Berbahagialah orang yang lapar dan haus akan kebenaran, karena mereka akan dipuaskan." Haus untuk melakukan firman Tuhan adalah salah satu sikap sebagai pengikut Kritus.

\section{Kristus Dapat Merasa Empati Terhadap Manusia yang Menderita}

Kristus dapat berempati bersama mereka yang sedang berada dalam penderitaan, karena Dia adalah juga manusia sejati yang pernah merasakan berbagai penderitaan dan pencobaan selama Dia melayani di dunia. Sebab oleh karena Ia sendiri telah menderita karena pencobaan, maka Ia dapat menolong mereka yang dicobai (Ibr. 2:18)

Masalah penderitaan menjadi salah satu hal membingungkan. Mengapa penderitaan diperlukan di dunia yang diatur oleh Tuhan yang sempurna? Mengapa penderitaan harus terjadi dan dialami oleh orang percaya? Bukankah Tuhan memiliki kekuatan untuk mencegah kejahatan dan penderitaan? Dia berkata bahwa Ia mengasihi semua orang terlebih mereka yang percaya, akan tetapi mengapa harus ada kemiskinan, rasa sakit, kemalangan, bahkan kematian? Apakah Allah melihat? Apakah Allah mengetahui? Bukankah Ia adalah kasih? Apakah Dia benar-benar peduli? Jawaban dari semua pertanyaan tersebut terjawab melalui penderitaan Yesus di kayu salib.

Allah bukan saja berempati terhadap penderitaan manusia tetapi Ia sendiri juga turut merasakan kelemahan-kelemahan manusia tetapi tidak

\footnotetext{
${ }^{66}$ Jonar Situmorang, 252.

${ }^{67}$ James M. Stalker, 152.
} 
berbuat dosa sehingga Ia dapat menolong mereka yang dicobai dan sedang menderita. Yesus peduli akan setiap pergumulan yang sedang dihadapi oleh setiap orang percaya. Ia mau supaya semua orang percaya sungguh-sungguh mengandalkan Dia dan percaya bahwa Ia sanggup menolong sebab Ia mengerti dan Ia yang memelihara kehidupan (1 Pet. $5: 7)$.

\section{Manusia Menerima Keselamatan Hanya Melalui Iman Bukan Melalui Usaha}

Keselamatan adalah karya Tuhan yang telah sempurna dan hanya diterima oleh manusia melalui Iman. Manusia tidak dapat menambahkan apapun termasuk perbuatan baik untuk keselamatannya seakan-akan karya Kristus belum mencukupi. Perbuatan baik manusia bukanlah untuk mendapatkan keselamatan tetapi itu dilakukan karena ia telah memperoleh keselamatan. Perbuatan baik manusia hanya sebagai ungkapan syukur atas keselamatan yang telah dianugerahkan oleh Allah. Sebab karena kasih karunia kamu diselamatkan oleh iman; itu bukan hasil usahamu, tetapi pemberian Allah, itu bukan hasil pekerjaanmu: jangan ada orang yang memegahkan diri (Ef. 2:8-9). Ungkapan ini memperkuat apa yang Yesus katakan kepada penjahat yang bertobat.

\section{Melaksanakan Amanat Agung Sebagai Tugas yang Harus Diselesaikan}

Yesus telah menyelesaikan tugas-Nya dengan tuntas di atas kayu salib. Hal ini ditandai dengan seruan tetelestai yang begitu keras yang keluar dari mulut-Nya. Seruan itu menyerukan isi hati terdalam Tuhan Yesus bagi orang percaya yang seakan-akan menyatakan bahwa bagian$\mathrm{Ku}$ sudah $\mathrm{Ku}$-selesaikan bagimu, sekarang adalah bagianmu. Pengikut Kristus dipercayakan untuk memberitakan Injil dan menjadi saksi sebagai tugas utama. Pauluspun menasihatkan Timotius untuk tetap memberitakan Injil dan menyelesaikannya sampai tuntas (2 Tim. 4:5). Untuk melakukan tugas itu, Yesus harus mengorbankan diri-Nya. Demikian juga orang Kristen harus siap berkorban menjadi saksi-Nya. (Kis. 1:8). Bahkan mungkin untuk memberitakan Injil, seseorang harus mempertaruhkan nyawa. ${ }^{68}$ Oleh karena segala kuasa di surga dan bumi telah diberikan kepada-Nya tidak ada alasan sebagai orang Kristen untuk tidak melaksanakannya (Mat. 28:18-20).

\section{Penyerahan Total Kepada Bapa}

Yesus kembali berseru dalam doa-Nya kepada Bapa. Ungkapan yang pertama Ia juga menggunakan Bapa - menyatakan hubungan yang begitu

\footnotetext{
${ }^{68}$ Jonar Situmorang, 256-257.
} 
akrab. Ungkapan keempat Ia mengucapkan Allah-Ku menyatakan kepemilikan yang teguh dan tidak dapat diambil oleh siapapun. Dan terakhir ungkapan ketujuh Ia kembali mengatakan Bapa menyatakan penyerahan diri-Nya kepada Bapa. Penulis menyimpulkan bahwa Yesus dalam masa kehidupan-Nya dan pelayanan-Nya di bumi selalu mengutamakan kepentingan Bapa. Yesus mengajarkan berdoa kepada para murid-Nya dalam kalimat utamanya menyebutkan jadilah kehendakMu di bumi seperti di surga (Mat. 6:10). Dalam doa-Nya di taman Getsemani Ia berkata: "Ya Bapa-Ku, jikalau sekiranya mungkin, biarlah cawan ini lalu dari pada-Ku, tetapi janganlah seperti yang Kukehendaki, melainkan seperti yang Engkau kehendaki." (Matius 26:39). Dalam doa selanjutnya Ia juga mengatakan: "Ya Bapa-Ku jikalau cawan ini tidak mungkin lalu, kecuali apabila Aku meminumnya, jadilah kehendak-Mu!" (Matius 26:42).

Dalam ungkapan-Nya yang terakhir ini Yesus ingin menyatakan bahwa seluruh hidup-Nya adalah dari Sang Bapa, oleh karena Bapa, dan untuk Bapa. Segala sesuatu adalah milik-Nya bahkan hidup ini pun milik-Nya, Bapa memiliki hak penuh atas kehidupan seseorang, dan Ia berkuasa untuk memberi hidup dan mengambilnya kembali. Sebab segala sesuatu adalah dari Dia, dan oleh Dia, dan kepada Dia: Bagi Dialah kemuliaan sampai selama-lamanya! (Rom. 11:36). Biarlah kita juga dapat berkata seperti Ayub: "Sebab TUHAN yang memberi, TUHAN yang mengambil, terpujilah nama TUHAN!" (Ayub 1:21). Kristus mati karena Ia menyerahkan nyawa-Nya! bukan hukuman salib yang membuat Kristus mati, melainkan karena Kristus sendiri yang rela menyerahkan nyawa-Nya. ${ }^{69}$

Penyerahan merupakan bentuk kepercayaan kepada Tuhan sebagai yang berkuasa dan memiliki hidup ini. Ia menciptakan segala sesuatu dan segala sesuatu tunduk kepada-Nya. Dengan demikian, orang kristen dapat memandang hidup ini dari sudut pandang yang berbeda. Seperti yang ditulis oleh Paulus dalam Roma 8:28: "Kita tahu sekarang, bahwa Allah turut bekerja dalam segala sesuatu untuk mendatangkan kebaikan bagi mereka yang mengasihi Dia, yaitu bagi mereka yang terpanggil sesuai dengan rencana Allah." Apa yang terjadi pada dalam kehidupan sebagai orang percaya adalah dalam rencana dan pemeliharaan Tuhan. Semuanya mendatangkan kebaikan bagi orang yang percaya kepadaNya. Kematian Yesus berada dalam tangan Tuhan. Ia menyerukan dengan suara yang nyaring hingga terdengar pada masa kini. Seruan yang menembus ruang dan waktu. Hati dan sanubari seseorang. Seruan yang menyatakan penyerahan diri-Nya ke dalam tangan Bapa. Menjelang ajalnya Yesus tetap dekat dengan Bapa-Nya dan Bapa-Nya tidak

${ }^{69}$ Trivena Ambarsari, Seri Pelajaran Irecs: Kristologi (Surabaya: Momentum, 2012), 18. 
meninggalkan-Nya. Dalam penderitaan yang berat sekalipun, Yesus masih tetap memasrahkan diri-Nya kepada Bapa di surga. ${ }^{70}$

Karya akhir Yesus berupa penyerahan diri secara utuh. Ia telah setia dalam ketaatan sebagai Anak sepanjang hidup-Nya, jadi sekarang pun Ia dapat tetap setia untuk tunduk kepada kehendak Allah Bapa. Yesus telah memberikan teladan kepada semua pengikut-Nya dalam semua jalan penyerahan, dalam hidup dan maut yakni Allah adalah Bapa yang dapat dipercaya dan diandalkan karena itu penyerahan total kepada-Nya merupakan hal yang penting sebab Dia-lah yang memelihara hidup.

\section{Kesimpulan}

Tujuh perkataan Yesus di kayu salib merupakan tujuh ucapan yang mencakup seluruh pengajaran mengenai kasih Allah bagi manusia. Kasih yang sulit untuk dipahami, sulit untuk dimengerti secara tuntas karena ia melebihi kapasitas serta rasio pemikiran manusia yang terbatas. Pernyataan kasih itu disimpulkan sebagai berikut: Pertama, ucapan pengampunan yang diucapkan Yesus mengajarkan bahwa prinsip pengampunan adalah mengasihi musuh. Mendoakan dan mengharapkan dia bertobat serta mengampuni segala dosa-dosanya bukan berarti membiarkan dia berdosa terus menerus. Ucapan pengampunan yang diucapkan oleh Yesus ialah bukan supaya orang-orang yang didoakan diampuni tanpa pertobatan, tetapi supaya mereka diampuni melalui pertobatan. Kedua, dalam perkataan-Nya yang kedua, Yesus menjamin orang berdosa yang bertobat dan percaya kepada-Nya akan bersamasama dengan Dia di Firdaus. Seruan jaminan kepastian yang diucapkan Yesus merupakan bentuk kasih yang menyelamatkan. Ketiga, Yesus adalah Allah yang peduli terhadap penderitaan umat yang dikasihi-Nya. Orang-orang yang sungguh-sungguh mengasihi Tuhan memiliki tanggung jawab untuk melakukan segala perintah Tuhan dan dalam segala hal mengasihi sesama. Keempat, Seruan ini mengajarkan mengenai kuasa dosa yang dahsyat sehingga Allah Bapa merelakan Anak-Nya yang sangat Ia kasihi, memikul beban dosa tanpa pertolongan dan perlindungan. Kelima, ucapan kelima inilah satu-satunya ucapan yang berhubungan dengan kesakitan jasmani yang Ia ucapkan dari atas kayu salib. Rasa haus Yesus menunjukkan bahwa Ia adalah benar-benar manusia. Ia adalah sumber air hidup yang rela menderita agar dapat menyelamatkan mereka yang datang kepada-Nya. Keenam, ucapan keenam ini bukanlah teriakan kekalahan, melainkan teriakan kemenangan. Ketaatan-Nya kepada kehendak Bapa hingga akhir hidupNya menandakan kasih-Nya yang begitu besar bagi manusia. Inilah kasih

\footnotetext{
${ }^{70}$ Jonar Situmorang, Via Dolorosa Membawa Kemenangan, 278.
} 
yang taat sampai mati. Ketujuh, ucapan terakhir Yesus menjelang kematian-Nya adalah sebuah doa. Di dalam doa-Nya itu Ia mengajarkan orang percaya bagaimana menghadapi kematian. Bentuk kasih yang penuh, terkandung di dalam penyerahan total kepada Allah.

\section{Kepustakaan}

Alkitab.Jakarta: Lembaga Alkitab Indonesia, 2009.

Ambarsari, Trivena. Seri Pelajaran Irecs: Kristologi. Surabaya: Momentum, 2012.

Bingham, G. 7 Sabda Salib. Bandung: Kalam Hidup, 2003.

Bruce, F. F. Ucapan Yesus yang Sulit. Malang: Literatur SAAT, 1999.

Chandra, Indi. Pilihan Anda Sudah Tepat. Malang: Gandum Mas, 2008.

Collins, Gerald O', SJ., Farrugia, Edward G. SJ. Kamus Teologi. Yogyakarta: Kanisius, 1997.

Davids, Peter H. Ucapan Yang Sulit Dalam Perjanjian Baru. Malang: Literatur SAAT, 2000.

Henry, Matthew. Tafsiran Matthew Henry: Injil Lukas 13-24. Surabaya: Momentum, 2009. 2009.

. Tafsiran Matthew Henry: Injil Yohanes 12-21. Surabaya: Momentum, 2009.

Hoekema, Anthony A. Diselamatkan oleh Anugerah. Surabaya: Momentum, 2008.

Hymers, R. L. "Rasa Haus Yesus di Kayu Salib." Diakses 10 April 2014. http://www.rlhymersjr.com/Online_Sermons_Indonesian/2010/01241 OPM_ThirstOfJesus.html

Lee, Jaerock. Pesan Salib. Yogyakarta: Andi, 2010.

Letlora, Alex. "7 Perkataan Yesus di Salib." Diakses 6 Februari 2014. http://alexletlora.com/index.php?ipage=143

Lumbantobing, Andar. Tudjuh Utjapan Tuhan Jesus di Kayu Salib. Djakarta: BPK, 1989.

Morris, Leon. Salib Yesus. Malang: Literatur SAAT, 2000.

Nggebu, Sostenis. Napak Tilas Jejak-Jejak Yesus. Bandung: Kalam Hidup, 2004.

Owen, John. Jaminan Keselamatan Kristen. Surabaya: Momentum, 2005.

Pasaribu, Marulak. Eksposisi Injil Sinoptik. Malang: Gandum Mas, 2005.

Ryken, Leland., Wilhoit, James C., Longman III, Tremper. Kamus Gambaran Umum. Surabaya: Momentum, 2011. 
Shenouda III, H. H. Pope. The Seven Words of Our Lord On The Cross. Dar El Tebaa El Kawmia, 1991.

Situmorang, Jonar. Via Dolorosa Membawa Kemenangan. Yogyakarta: Andi, 2011.

Stalker, James M. Sengsara Tuhan Yesus. Jakarta: Yayasan Komunikasi Bina Kasih, 2008.

Stott, John. Kristus yang Tiada Tara. Surabaya: Momentum, 2008.

Tong, Stephen. 7 Perkataan Salib. Surabaya: Momentum, 2010.

Van De Kamp, Wilkin. 7 Mujizat Salib Golgota. Malang: Gandum Mas, 2010.

Walvoord, John F. Yesus Kristus Tuhan Kita. Surabaya: YAKIN, 1969.

Zwemer, Samuel M. Kemuliaan Salib. Jakarta: Yayasan Komunikasi Bina Kasih, 2002. 